九州大学学術情報リポジトリ

Kyushu University Institutional Repository

\title{
Chemical Cross-linking of Actin and Myosin Subfragment-1 in Rigor Complex
}

\section{Liaw, Ken Jyh-Fang}

Mckey Food Servies Limited

Mori, Sunao

Laboratory of Chemistry and Technology of Animal Products, Division of Applied Biological

Chemistry, Department of Bioscience and Biotechnology, Faculty of Agriculture, Kyushu University

Hasimoto, Sumie

Laboratory of Chemistry and Technology of Animal Products, Division of Applied Biological

Chemistry, Department of Bioscience and Biotechnology, Faculty of Agriculture, Kyushu University

Sugimitsu, Miyako

他

https://doi.org/10.5109/4571

出版情報: 九州大学大学院農学研究院紀要. 49 (1)，pp.111-118，2004-02-01. Faculty of Agriculture, Kyushu University

バージョン :

権利関係 : 


\title{
Chemical Cross-linking of Actin and Myosin Subfragment-1 in Rigor Complex
}

\section{Ken Jyh-Fang LIAW', Sunao MORI, Sumie HASHIMOTO, Miyako SUGIMITSU, Toshiya HAYASHI ${ }^{2}$, Minoru YAMANOUE ${ }^{3}$, Ryuichi TATSUMI, Yoshihide IKEUCHI and Tatsumi ITO*}

\author{
Laboratory of Chemistry and Technology of Animal Products, Division of Applied \\ Biological Chemistry, Department of Bioscience and Biotechnology, Faculty \\ of Agriculture, Kyushu University, Fukuoka 812-8581, Japan \\ (Received October 31, 2003 and accepted November 14, 2003)
}

\begin{abstract}
Chemical cross-linking of actin and myosin subfragment-1 (S-1) was investigated under various conditions. Actin and S-1 were cross-linked with the aid of zero-angstrom cross-linker 1-ethyl-3-(3-(dimethylamino)propyl) carbodiimide (EDC). Three new bands having larger molecular weight than those of two subunits of S-1 and one new, band having smaller molecular weight than the sub-units of S-1 appeared on electrophoretograms after the cross-linking reaction. These new bands were formed by cross-linking between actin and subcomponents of S-1. The extent of cross-linking decreased with increasing the ionic strength of reaction mixtures and also decreased with increasing the concentration of ATP. The extent of cross-linking between S-1 and actin prepared from fresh muscle was not appreciably smaller than that of those proteins prepared from postmortem muscle in rigor (stored at $0^{\circ} \mathrm{C}$ for $24 \mathrm{hr}$ ) and even that of those proteins prepared from muscle stored for more prolonged period ( $168 \mathrm{hr}$ ).

To elucidate the effect of paratropomyosin on actin-S-1 interaction, the extent of actin-S-1 complex formation in the absence or presence of paratropomyosin during the cross-linking reaction was investigated. As a result, the formation of new bands was reduced after the addition of paratropomyosin, while almost no change of the intensity of S-1 heavy chain $(90 \mathrm{kDa})$ was observed. The result indicates that paratropomyosin is involved in the weakening of actin-myosin interaction during the development of the resolution of rigor.
\end{abstract}

\section{INTRODUCTION}

The interaction between actin and myosin in postmortem muscle cells influences not only the rigidity of postmortem muscle cells but also the properties of heat-induced gels of those proteins in meat products (Lawrie, 1985; Greaser, 1986; Pearson, 1987; Wismer-Pedersen, 1987). However, there is a controversy about the intensity of the interaction between actin and myosin in postmortem muscle. Fujimaki et al. (1965) have found that "myosin B" prepared from postmortem muscle is more easily dissociated into its components than that from fresh muscle by the addition of 1-5 mM ATP. Since then, it

1 Mckey Food Services Limited, Qing Shui He Warehouse District, Hong Ling North Road, Shenzhen PRC, Post Code 518024, Hong Kong

2 Laboratory of Food Science and Technology, Faculty of Agriculture, Meijo University, Nagoya 468-8502, Japan

3 Department of Biofunctional Chemistry, Faculty of Agriculture, Kobe University, Kobe 657-0013, Japan

* Corresponding author (E-mail: tito@agr.kyushu-u.ac.jp) 
has been widely considered that actin-myosin interaction is weakened during postmortem storage of muscle at cold temperatures. However, Wolfe and Samejima (1976) have studied ATP dissociation of chicken actomyosin by ultracentrifugal and viscometric methods and have demonstrated that postmortem ageing of chicken muscle has no effect on the dissociation of actin and myosin. After the development of SDS-polyacrylamide gel electrophoresis technique, the publications of the above mentioned paper revealed that myosin B contains troponin, tropomyosin, $\alpha$-actinin and other minor components in addition to actin and myosin (Penny, 1970; Starr and Offer, 1971; Offer et al., 1973; Park et al., 1975). Therefore, the necessity for investigating the effect of these minor components on the actin-myosin interaction in postmortem muscle has been required. Ikeuchi et al. (1980) have found that the change of actin-myosin interaction during postmortem storage of muscle is not appreciably modified by the regulatory proteins, troponin and tropomyosin. However, Takahashi et al. (1987) and Yamanoue and Takahashi (1988) have indicated the implication of paratropomyosin (a new regulatory protein having the same molecular weight as that of tropomyosin) in weakening the actin-myosin interaction in postmortem muscle. With regard to the actin-myosin interaction itself, on the other hand, Ito et al. (1978) have shown that the affinity of actin to myosin increases with increasing postmortem storage time at $0^{\circ} \mathrm{C}$ by calculating $\mathrm{Km}$ values of actin activated-heavy meromyosin ATPase (Eisenberg et al., 1968). These results suggest that actin-myosin interaction itself increases for at least 1 week when muscles are stored at $0^{\circ} \mathrm{C}$ and the interaction between myosin and actin may be weakened by the interference of other minor components of myofibrillar proteins, such as paratropomyosin.

Zero angstrom cross-linkers such as 1-ethyl-3-(3-dimethylamino)propyl) carbodiimide (EDC) and 1-cyclohexyl-3-(2-morpholinoethyl) carbodiimide (CMC) have been successfully used for the formation of peptide bonds between two proteins which had non-covalently contacted each other (Sheehan et al., 1961; Sheehan et al., 1965; Hoare and Koshland, 1967). Sutoh (1983) has shown an actin-binding site of myosin molecule by cross-linking reaction with EDC when the two different proteins contact each other to form rigor complex. The purpose of the present study was to investigate the interaction of actin and myosin subfragment-1 (S-1) under various conditions by using zero angstrom cross-linker EDC. Especially, the difference in actin-myosin interaction between muscle immediately after slaughter and postmortem muscles was the major purpose of the present study. The effect of paratropomyosin on the interaction of actin and S-1 was also another major purpose of the present study.

\section{MATERIALS AND METHODS}

\section{Materials}

Rabbits were anaesthetized with pentobarbital prior to exsanguination. After dressing, rabbit carcasses were dipped in cold $10 \mathrm{mM}$ sodium azide for a few seconds, and then the carcasses were wrapped in polyethylene bags and stored in an ice box at $0^{\circ} \mathrm{C}$ until use. Actin and myosin were prepared either from muscles immediately after slaughter (fresh muscle) or from muscles stored at $0^{\circ} \mathrm{C}$ for $168 \mathrm{hr}$ (postmortem muscle) according to the procedure of Spudich and Watt (1971) and Tonomura et al. (1960), respectively. Preparation of S-1 was made by the method of Weeds and Taylor (1975): $10 \mathrm{mg} / \mathrm{ml}$ 
myosin in $0.12 \mathrm{M} \mathrm{NaCl}, 20 \mathrm{mM}$ sodium phosphate ( $\mathrm{pH} 7.0$ ), $10 \mathrm{mM}$ ethylenediaminetetraacetic acid (EDTA) was digested with $\alpha$-chymotrypsin (myosin: $\alpha$-chymotrypsin $=$ $200: 1$ ) at $25^{\circ} \mathrm{C}$ for $10 \mathrm{~min}$. The digestion was quenched by the addition of $10 \mathrm{mM}$ phenylmethanesulfonyl fluoride (PMSF). Then, the digested product was dialyzed against 100 vol. of $0.1 \mathrm{M} \mathrm{NaCl}, 10 \mathrm{mM}$ imidazole-HCI (pH 7.0), $2 \mathrm{mM} \mathrm{MgC1}_{2}$ at $0{ }^{\circ} \mathrm{C}$ for $24 \mathrm{hr}$ by exchanging the dialyzing solution with fresh one thrice. The resulting dialyzate was clarified by centrifugation at $25,000 \mathrm{~g}$ for $30 \mathrm{~min}$ at $0^{\circ} \mathrm{C}$.

Paratropomyosin was prepared from rabbit fresh muscle according to the procedure of Takahashi et al.(1985).

\section{Cross-linking of actin and S-1}

After dialysis against 100 vol. of $0.1-0.5 \mathrm{M} \mathrm{NaCl}, 10 \mathrm{mM}$ imidazole- $\mathrm{HCl}(\mathrm{pH} 7.0), 2 \mathrm{mM}$ $\mathrm{MgCl}_{2}$ in the presence or absence of $1-5 \mathrm{mM}$ ATP at $0^{\circ} \mathrm{C}$ overnight, $0.5 \mathrm{ml}$ of S-1 $(1 \mathrm{mg} / \mathrm{ml})$ and $0.5 \mathrm{ml}$ of actin $(1 \mathrm{mg} / \mathrm{ml})$ were mixed and resulting mixture was incubated at $25^{\circ} \mathrm{C}$ for $10 \mathrm{~min}$ in order to form regor complex. Then, varying amounts of EDC dissolved in the above dialyzing buffer were added to the mixture (Concentrations of EDC in the reaction mixtures were $33,16.7,9.0,5.0,2.5,1.0,0.5$ and $0.2 \mathrm{mM}$ in order), followed by the incubation at $25^{\circ} \mathrm{C}$ for $1 \mathrm{hr}$. During the incubation, S-1 and actin molecules in rigor complex form intermolecular peptide linkages between amino and carboxyl groups of those proteins. The cross-linking reaction was quenched by the addition of approximately 10 fold excess of $\beta$-mercaptoethanol. The same cross-linking reaction of actin and $\mathrm{S}-1$ was also performed in the presence or absence of paratropomyosin.

\section{Detection of chemically cross-linked rigor complex}

Immediately after the cross-linking reaction was quenched, an equal volume of 2 -fold concentration of sample buffer (1\% SDS, $10 \mathrm{mM}$ Tris-HCl, $\mathrm{pH} 6.8,1 \mathrm{mM} \beta$-mercaptoethanol, $1 \mathrm{mg} / \mathrm{ml}$ bromphenol blue, $20 \%$ glycerol) was mixed with the reaction mixtures. The resulting sample mixtures were electrophoresed on gradient gels (7.5-17.5\% polyacrylamide gels) containing 1\% SDS according to the procedure of Laemmli (1970).

\section{Western-blotting of EDC treated muscle proteins}

Western-blotting of SDS-PAGE of chemically cross-linked products was performed as described by Towbin et al. (1979). The detection of main bands on PVDF membrane was made by using rabbit anti-skeletal myosin and anti-actin antibodies (Sigma), and western blot kit (POTEIN DETECTER; KPL).

\section{RESULTS AND DISCUSSION}

Figure 1 shows SDS polyacrylamide gel electrophoretograms of actin (MW=42k dalton), $\mathrm{S}-1$ and the reaction mixtures of $\mathrm{S}-1(0 \mathrm{hr})$ and actin $(0 \mathrm{hr})$ in $0.1 \mathrm{M} \mathrm{NaCl}$ at $\mathrm{pH}$ 7.0 , a preferable condition for the formation of rigor complex, after the treatment with varying concentrations of EDC. S-1 preparation in this experiment showed two major bands (S1a and S1b, whose molecular weights were approximately 116 and $90 \mathrm{k}$ dalton, respectively) and two minor bands, which supposedly be proteolytic fragments (S1f1 and $\mathrm{S} 1 \mathrm{f} 2)$ of Sla, in addition to the bands of myosin light chains. The intensity of actin ( $0 \mathrm{hr})$ 


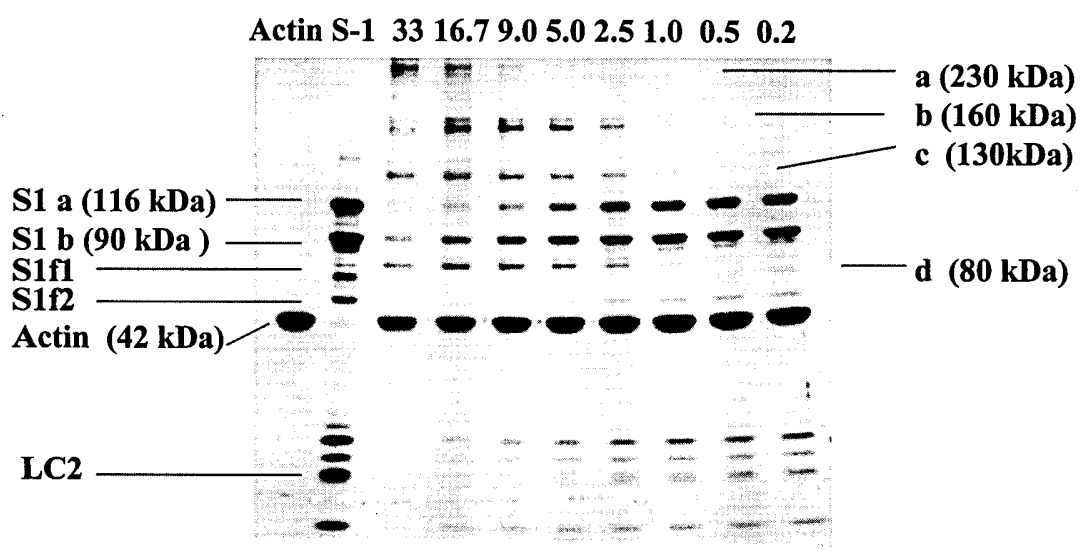

Fig. 1. SDS-PAGE patterns of chemically cross-linked products of actin and S-1 prepared from fresh muscle $(0 \mathrm{hr})$ in $10 \mathrm{mM}$ imidazole- $\mathrm{HCl}(\mathrm{pH} 7.0)$ containing $0.1 \mathrm{M} \mathrm{NaCl}$. Lanes $33,16.7,9.0,5.0,2.5,1.0,0.5$, and 0.2 indicate the concentration (mM) of EDC in the cross-linking reaction mixtures. MW (kD) indicates molecular weight ( $\mathrm{k}$ dalton). Sla and S1b indicate major fragments of S-1 and Slfl and Slf2 indicate minor fragments of S1. LC2 indicates myosin light chain-2. Numbers on the right side indicate molecular weight in $\mathrm{k}$ dalton $(\mathrm{kDa})$.

and subcomponents of S-1 (0 hr) decreased, while four new bands appeared after the treatment with EDC. In addition, the intensity of the four bands increased with increasing the concentration of EDC. From the estimation of the molecular weight of these new bands ( $a, b, c$ and $d$, whose molecular weights were estimated to be approximately, 230, 160, 130 and $80 \mathrm{k}$ dalton), it is likely that band $\mathrm{b}$ is a complex of actin and $\mathrm{S}-1 \mathrm{a}$ (1:1 complex), whereas band $\mathrm{c}$ is derived from the binding of actin and $\mathrm{S}-1 \mathrm{~b}$ (1:1 complex), although the bands $b$ and $c$ show double bands. However, it is obscure why the bands $b$ and $c$ show double bands. The appearance of such double bands may be due to a partial cleavage of $\mathrm{S}-1 \mathrm{a}$ before and after the cross-linking reaction. The molecular weight of band $d$ is smaller than that of $S-1 b$, and the intensity of the band of myosin light chains, especially light chain-2, was decreased at any time when the band $\mathrm{d}$ appeared. These results indicate that the band d might be composed of one part of actin and two parts of myosin light chains. Band a having larger molecular weight than band $b$ was clearly detected at $2.5 \mathrm{mM} \mathrm{EDC}$, while the formation of the bands b-d was detected even at $0.5 \mathrm{mM}$ EDC. The difference in the sensitivity of protein complex against EDC suggests that there is a delicate difference in the affinity of the protein complex between rigor complex and the complex produced by simple association of $\mathrm{S}-1$ under the condition of low ionic strength. Therefore, band an might be an association product of the heavy chain moieties of $\mathrm{S}-1$.

Figure 2 also shows the electrophoretograms of the mixture of actin $(0 \mathrm{hr})$ and $\mathrm{S}-1$ $(0 \mathrm{hr})$ in $0.5 \mathrm{M} \mathrm{NaCl}$ at $\mathrm{pH} 7.0$. Similar tendency of the cross-linking reaction between actin and S-1 as in the case of Fig. 1 was observed in this condition, too, although the band of S-1a was partially degraded into fragments (S1fl and S1f2). However, the forma- 


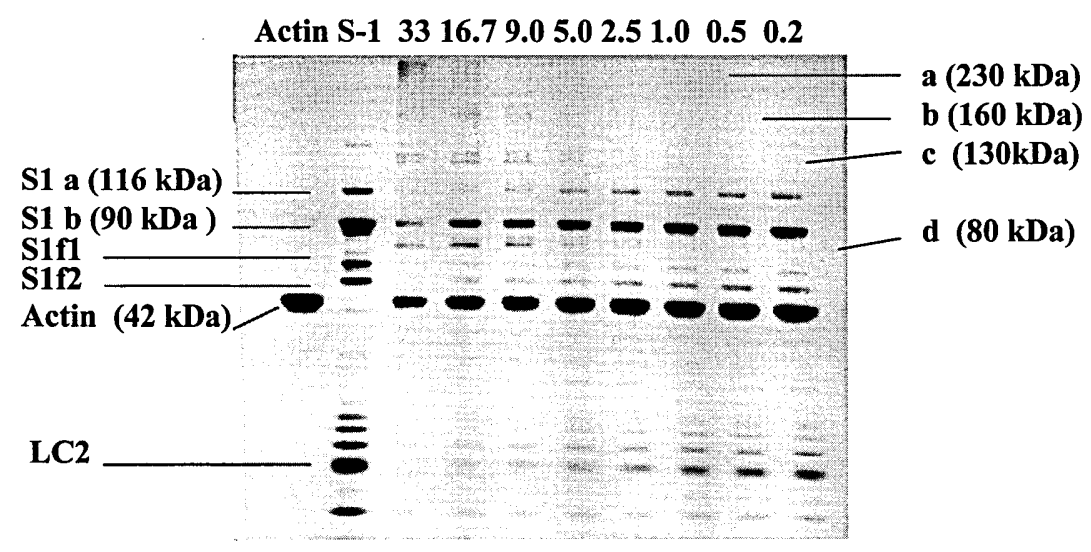

Fig. 2. SDS-PAGE patterns of chemically cross-linked products of actin and S-1 prepared from fresh muscle $(0 \mathrm{hr})$ in $10 \mathrm{mM}$ imidazole- $\mathrm{HCl}(\mathrm{pH} 7.0)$ containing $0.5 \mathrm{M} \mathrm{NaCl}$. Lanes 33, 16.7, 9.0, 5.0, 2.5, 1.0, 0.5, and 0.2 indicate the concentration (mM) of EDC in the cross-linking reaction mixtures.

tion of new bands was markedly reduced at every concentration of EDC, i.e., the formation of new bands (bands $b$ and $c$ ) was only detectable at more higher concentrations of EDC than in the case of Fig. 1. For example, band a clearly appeared at $9.0 \mathrm{mM}$ EDC or above, and bands $\mathrm{b}$ and $\mathrm{c}$ at 5.0 and $2.5 \mathrm{mM}$ EDC, respectively. Quite similar result was also observed in the case of rigor complex formed from actin (168hr) and S-1 (168hr) (Data not shown). Figure 3 shows the electrophoretograms of the mixture of S-1 (O hr) and actin $(0 \mathrm{hr})$ in $0.1 \mathrm{NaCl}, 10 \mathrm{mM}$ imidazole-HCI $(\mathrm{pH} \mathrm{7.0)}$ in the presence of $1.0 \mathrm{mM}$ ATP. As can be clearly seen in this Fig. 3, the formation of the new bands were greatly reduced after the addition of ATP, although S-1a was extensively degraded into fragments (S1f1 and S1f2) in this experiment. Quite similar result was also observed for the mixtures of actin (168 hr) and S-1 (168 hr) (Data not shown). These results (Figs. 2 and 3) also inversely indicate that EDC treatment preferentially forms covalently bonded complex between actin and S-1 in rigor state. These new bands which appeared after the cross-linking reaction between actin and $\mathrm{S}-1$ in various conditions were confirmed as actin-S-1 complex by immunoblotting for bands $b$ and $c$ (Data not shown). Figure 4 shows the electrophoretograms of the reaction mixture of S-1 (168hr) and actin ( $168 \mathrm{hr})$. Quite similar results as in the case of the mixture of $\mathrm{S}-1(0 \mathrm{hr})$ and actin $(0 \mathrm{hr})$ were observed after EDC-treatment; extent of the formation of the new bands (bands a-d) in rigor complex composed of postmortem actin and $\mathrm{S}-1$ was quite similar to that of fresh actin and $\mathrm{S}-1$, i.e., band a clearly appeared at $5.0 \mathrm{mM}$ EDC or above, and bands b and c also clearly appeared at $0.5 \mathrm{mM} \mathrm{EDC}$, as in the case of fresh actin and $\mathrm{S}-1$. This result indicates that chemical cross-linking reaction for analyzing the affinity of actin and S-1 in rigor complex may be a less sensitive procedure than kinetic analysis of actin-activated heavy meromyosin ATPase (Ito et al., 1978). However, the present result, at least, reconfirmed that the affinity of actin and myosin in postmortem muscle isn't smaller than 


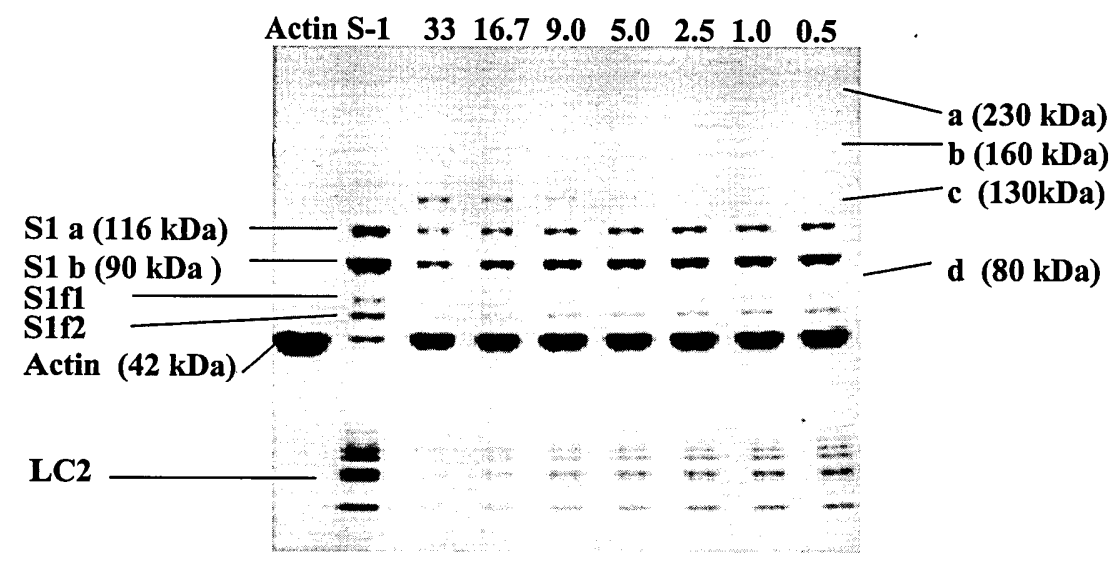

Fig. 3. SDS-PAGE patterns of chemically cross-linked products of actin and S-1 prepared from fresh muscle $(0 \mathrm{hr})$ in $10 \mathrm{mM}$ imidazole- $\mathrm{HCl}(\mathrm{pH} 7.0)$ containing $0.1 \mathrm{M} \mathrm{NaCl}$ in the presence of $1.0 \mathrm{mM}$ ATP. Lanes $33,16.7,9.0,5.0,2.5,1.0$ and 0.5 indicate the concentration $(\mathrm{mM})$ of EDC in the cross-linking reaction mixtures.

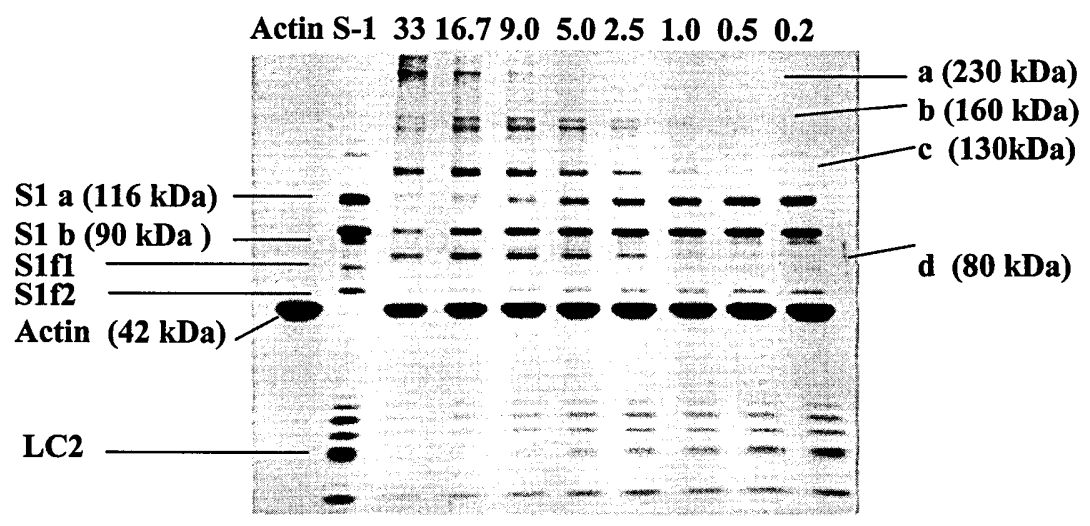

Fig. 4. SDS-PAGE patterns of chemically cross-linked products of actin and S-1 prepared from postmortem muscle $(168 \mathrm{hr}$ ) in $10 \mathrm{mM}$ imidazole-HCl ( $\mathrm{pH} 7.0)$ containing $0.1 \mathrm{M} \mathrm{NaCl}$. Lanes $33,16.7,9.0,5.0,2.5,1.0,0.5$, and 0.2 indicate the concentration (mM) of EDC in the cross-linking reaction mixtures.

that of fresh muscle. In other words, the present results indicate that the weakening of actin-myosin interaction in postmortem muscle is not due to a simple weakening reaction at crossbridges of rigor complex. Therefore, there is a possibility that regulatory proteins other than tropomyosin-troponin system, such as paratropomyosin, may be involved in the modification of actin-myosin interaction during the development of the resolution of rigor. 


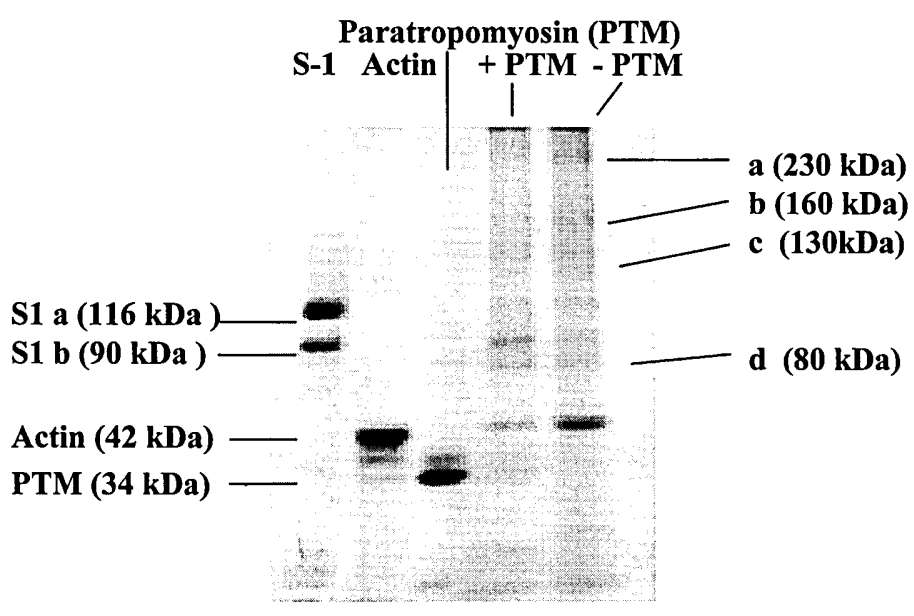

Fig. 5. SDS-PAGE patterns of chemically cross-linked products of actin and S-1 prepared from fresh muscle $(0 \mathrm{hr})$ in $0.1 \mathrm{M} \mathrm{NaCl}, 10 \mathrm{mM}$ imidazole- $\mathrm{HCl}(\mathrm{pH} 7.0)$ containing $16.7 \mathrm{mM}$ EDC in the absence or presence of PTM (actin : PTM=3:1; as weight ratio).

Figure 5 shows that the cross-linking between actin and S-1a/S-1b induced by EDC was completely diminished by the addition of paratropomyosin. No new bands larger than S-1 appeared after the cross-linking reaction. This result clearly indicate that actin-myosin interaction is interfered by paratropomyosin. According to the hypothesis of Takahashi (1996), the paratropomyosin is released from A-I junction, originally localized site in aged postmortem muscle, and then binds to the vicinity of myosin binding site of actin molecule. Thereby actin-myosin interaction is dissociated. This dissociation is one of the reasons of the tenderization of muscle during postmortem storage at cold temperatures. The result of Fig. 5 strongly supports this hypothesis.

\section{ACKNOWLEDGEMENT}

We thank Dr. K. Sutoh, Department of Chemistry, University of Tokyo, and Dr. K. Tawada, Department of Biology, Faculty of Science, Kyushu University, for their technical suggestions.

\section{REFERENCES}

Eisenberg, E. and C. Moos 1968 The adenosine triphosphatase activity of acto-heavy-meromyosin. A kinetic analysis of actin activation. Biochemistry, 7: 1486-1489

Fujimaki, M., N. Arakawa, A. Okitani and O. Takagi 1965 The dissociation of "myosin B" from the stored rabbit muscle into myosin A and actin and its interaction with ATP. Agric. Biol. Chem., 29: 700-701

Greaser, M. L. 1986 In: Muscle as Food., ed. by P. J. Bechtel, Academic Press Inc., New York, p 37

Hoare, D. G., D. E. Jr. Koshland 1967 A method for the quantative modification and estimation of carboxylic acid groups in proteins. J. Biol. Chem., 242: 2447-2453

lkeuchi, Y., T. Ito and T. Fukazawa 1980 Change of regulatory activity of tropomyosin and troponin on 
acto-heavy meromyosin ATPase during postmortem storage of muscle. J. Food Sci., 45: 13-16, 20

Ito, T., S. K. Sung, T. Fukazawa 1978 Change of acto-heavy meromyosin ATPase of rabbit skeletal muscle during postmortem storage. J. Agric. Food Chem., 26: 324-326

Laemmli, U. K. 1970 Cleavage of structural proteins during the assembly of the head of bacteriophage. Nature, 227: $680-685$

Lawrie, R. 1985 Meat Science, Elsevier Publishing Co, London, p. 169

Offer, G., C. Moos and R. Starr 1973 A new protein of the thick filaments of vertebrate skeletal myofibrils. J. Mol. Biol., 74: 653-676

Park, H. K., M. Muguruma, T. Fukazawa and T. Ito 1975 Relationship between superprecipitating activity and constituents of myosin B prepared from normal and PSE porcine skeletal muscle. Agric. Biol. Chem., 39: 1363-1370

Pearson, A. M. 1987 In: The Science of Meat and Meat Products, 3 rd Ed. ed. by J. F. Price and B. S. Schweigert, Food and Nutrition Inc., Westport, Connecticut, p. 155

Penny, IF. 1970 Conditioning of bovine muscle II. Change in the composition of extracts of myofibrils after conditioning. J. Sci. Food Agric., 21: 303-306

Sheehan, J. C., P. A. Cruickshank and G. L. Boshart 1961 A convenient synthesis of water-soluble carbodiimides. J. Org. Chem., 26: 2525-2528

Sheehan, J. C., J. Preston and P. A. Cruickshank 1965 A rapid synthesis of oligopeptide derivatives without isolation of intermediates. J. Am. Chem. Soc., 87: 2492-2493

Spudich J. A. and S. Watt 1971 The regulation of rabbit skeletal muscle contraction. I. Biochemical studies of the interaction of the tropomyosin-troponin complex with actin and the proteolytic fragments of myosin. J. Biol. Chem., 246: 4866-4871

Starr, R and G. Offer 1971 Polypeptide chains of intermediate molecular weight in myosin preparations. FEBS Lett., 15: 40-44

Sutoh, K. 1983 Mapping of actin-binding sites on the heavy chain of myosin subfragment 1 . Biochemistry, 22: 1579-1585

Takahashi, K 1996 Structural weakening of skeletal muscle tissue during postmortem ageing of muscle: The non-enzymatic mechanism of meat tenderization. Meat Sci., 47: S567-580

Takahashi, K., F. Nakamura, A. Hattori and M. Yamanoue 1985 Paratropomyosin: A new myofibrillar protein that modifies the actin-myosin interaction in postrigor skeletal muscle. I. Preparation and characterization. J. Biochem., 97: 1043-1051

Takahashi, K., M. Yamanoue, T. Murakami, T. Nishimura and R. Yoshikawa 1987 Paratropomyosin, a new myofibrillar protein, weakens rigor linkages formed between actin and myosin. J. Biochem., 102: 1187-1192

Tonomura, Y., S. Tokura, K. Sekiya and K., Imamura 1961 Influence of solvent composition on the molecular shape and the enzymic activity of myosin A. Arch. Biochem. Biophys., 95: 229-236

Towbin H, T. Staehelin and J. Gordon 1979 Electrophoretic transfer of proteins from polyacrylamide gels to nitrocellulose sheets: procedure and some applications. Proc. Natl. Acad. Sci. USA., 76 : $4350-4354$

Weeds, A. G. and R. S. Taylor 1975 Separation of subfragment-1 isoenzymes from rabbit skeletal muscle myosin. Nature, 257: 54-56

Wismer-Pedersen, J. 1987 In: The Science of Meat and Meat Products 3rd Ed, ed. by J. F. Price and B. S. Schweigert, Food \& Nutrition Press Inc., Westport, Connecticut, p. 141

Yamanoue, M and K. Takahashi 1988 Effect of paratropomyosin on the increase in sarcomere length of rigor-shortened skeletal muscles. J. Biochem., 103: 843-847 